THE KURUME MEDICAL JOURNAL

Vol. 26, No. 4, p. 377-379, 1979

\title{
DESENSITIZATION OF BULLFROG ATRIUM MUSCLE TO THE MUSCARINIC ACTION OF ACETYLCHOLINE ON ITS ACTION POTENTIAL
}

\author{
TAKAYUKI TOKIMASA, HIROSHI HASUO, KYOZO KOKETSU ${ }^{11}$ \\ AND SHOICHI MINOTA ${ }^{2)}$
}

Department of Physiology, Kurume University School of Medicine, Kurume, 830'1, and Department of Physiology, Saga Medical School, Saga, 840-O12), Japan

Received for publication October 12, 1979

\begin{abstract}
Decreases in the amplitude and duration of the action potential of bullfrog atrium muscle by the muscarinic action of ACh or carbachol, were found to be restored to a certain extent when the application of ACh or carbachol was sustained. This suggests that the muscarinic receptor-ion channel complex which is responsible for these decreases shows the desensitization to the action of $\mathrm{ACh}$ or its agonist.
\end{abstract}

\section{INTRODUCTION}

Transmitters released from presynaptic nerve terminals act on the subsynaptic membrane of target cells and induce postsynaptic potential by changing: the subsynaptic membrane conductance. Such a change in the membrane conductance is thought to be caused by an activation of the receptor-ion channel complex located at the subsynaptic membrane. In neuromuscular junctions of skeletal muscle, the sensitivity of end-plate to acetylcholine (ACh) is depressed during a prolonged application of $\mathrm{ACh}$ or its agonists, and such a decrease of the sensitivity of membrane receptor-ion channel complex is called desensitization (Thesleff, 1955; Katz and Thesleff, 1957). This desensitization is one of most interesting nature of the receptor-ion channel complex.

Another action of transmitters is their regulatory actions on the action potential of target cells. For examples, transmitter substances, such as ACh and catecholamine, are able to regulate the size and time course of action potentials of heart muscle or sympathetic ganglion cells (Koketsu and Minota, 1975 ; Kuba and Koketsu, 1975, 1976 ; Minota and Koketsu, 1977). Such an effect of transmitters must be exerted by acting on ion channels, which are responsible for the production of action potentials. The fact that a transmitter is able to change the configulation of action potentials, suggests that these channels compose receptor-ion channel complexes. In connection with this suggestion, question is arised if these receptor-ion channel complexes show desensitization, like those of subsynaptic membrane producing postsynaptic potentials.

The present experiment was initiated for the purpose to test if changes in the action potentials of heart muscle, which were caused by the action of a transmitter, show desensitization. The present paper reports that changes in 
the action potential of heart muscle, being caused by the action of $\mathrm{ACh}$, are restored during a prolonged application of ACh, suggesting that the receptor-ion channel complex, which is responsible for these changes of action potential, shows the desensitization to the muscarinic action of $\mathrm{ACh}$.

\section{METHODS}

Strips $(1 \times 7 \mathrm{~mm}$ in size $)$ of quiescent muscle fiber bundles excised from the atrium of bullfrogs (Rana catesbeiana) were used in the present experiment. A preparation was continuously perfused with a solution during experiment and action potential were induced by applying electrical current ( $1 \mathrm{msec}$ duration) directly to the preparation through a pair of platinum electrode. Action potentials were recorded intracellularly by use of glass microelectrode filled with $3 \mathrm{M} \mathrm{KCl}$. In order to test the effect of a drug, superfusion medium was changed from the Ringer to the Ringer containing this drug in a desired concentration. Ionic composition of the Ringer solution is as follows : $112 \mathrm{mM} \mathrm{NaCl}, 2 \mathrm{mM} \mathrm{KCl}, 1.8 \mathrm{mM}$ $\mathrm{CaCl}_{2}, 2.4 \mathrm{mM} \mathrm{NaHCO}$, and $2.5 \mathrm{mM}$ glucose. Drugs used in the present experiment was acetylcholine chloride (Wako) and carbachol (Tokyo Kasei).

\section{RESULTS}

The value of resting membrane potential recorded from present preparations was ranged between $-85 \sim-95 \mathrm{mV}$. The action potential of these preparations was induced by repetitive electrical pulse stimulations of which frequency was $0.2-0.3 \mathrm{~Hz}$. An example of action potentials recorded in the present experiments is seen in record A-1 of Fig. 1. Recorded action potentials were very steady and can be recorded for more than 1 hour while muscle was impaled by a microelectrode. When $\mathrm{ACh}$ $\left(5.5 \times 10^{-7} \mathrm{M}\right)$ or carbachol $\left(5 \times 10^{-7} \mathrm{M}\right)$ was added to the superfusion solution (Ringer solution), the amplitude and duration of the action potential were markedly depressed within 30-60 sec (see record A-2 of Fig. 1).

An extremely interesting phenomenon which was found in the present

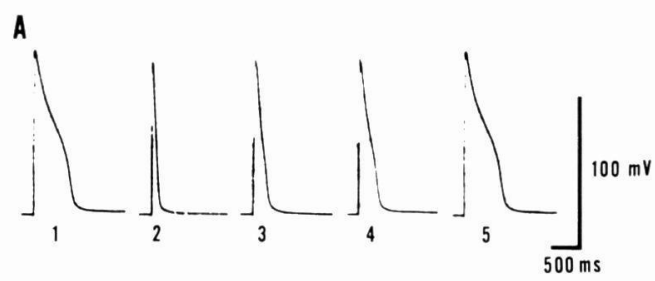

B ACh $5.5 \times 10^{-7} \mathrm{M}$

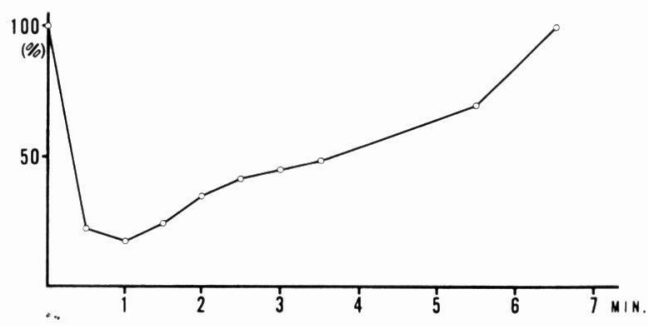

Fig. 1. Desensitization of action potential changes caused by the muscarinic action of $\mathrm{ACh}$ in bullfrog atrium muscle (resting potential, $-90 \mathrm{mV}$ ). A : Record 1 is a control action potential recorded in the Ringer solution and records 2,3 and 4 were recorded 1 , 2, 3 min after an addition of $\mathrm{ACh}\left(5.5 \times 10^{-7}\right.$ M), respectively. Record 5 was taken $3 \mathrm{~min}$ after withdrawal of ACh. Note the restoration of the amplitude and duration of action potential during a sustained application of $\mathrm{ACh}$. B: The duration of action potentials, which was measured at the potential level of $20 \%$ of total amplitude of control action potential, is plotted against time. The duration of control action potential is taken as $100 \%$. Note the increase of duration during a prolonged application of $\mathrm{ACh}$. 
experiment was the restoration of depressed action potential in the presence of ACh or carbachol. In other words, both the amplitude and duration of action potentials, which were decreased by the action of ACh or carbachol, were gradually increased during a prolonged application of $\mathrm{ACh}$ or carbachol. An example of these experiments is shown in Fig. 1. As seen in this figure, action potentials which were initially markedly depressed by ACh shows a gradual restoration to a certain extent during a sustained application of this drug; it was completely restored after ACh was withdrawn.

\section{DISCUSSION}

Decreases in the amplitude and dura tion of the action potential of atrium muscle by the muscarinic action of ACh or carbachol were thought to be caused by an increase of the $K$ conductance which is responsible for the background time-independent $\mathrm{K}$ current (cf. Noble, 1975). According to a recent paper (Giles and Noble, 1976), however, these decreases in ACh-containing solution was explained as a result of a reduction of the slow inward current. The present experiment clearly demonstrates that the changes in both amplitude and duration of action potential of artium muscle are restored during a prolonged application of ACh or its agonist. This suggests that the muscarinic receptor-ion channel complex, which is responsible for the changes in the action potential in ACh-containing Ringer solution, shows the desensitization to the action of $\mathrm{ACh}$. Whatever this channel is for the background $\mathrm{K}$ current or for the slow inward current, this muscarinic receptor-ion channel complex clearly shows the desensitization, like the nicotinic receptor-ion channel complex of the end-plate, to a prolonged application of $\mathrm{ACh}$ or its agonist.

\section{ACKNOWLEDGMENTS}

This study was supported by a Grant-inAid for Scientific Research from the Ministry of Education, Science and Culture of Japan.

\section{REFERENCES}

Giles, W. and Noble, S. J. (1976). Changes in membrane currents in bullfrog atrium produced by acetylcholine. J. Physiol, Lond. 261, 103-123.

KAtz,B. and Thesleff,S. (1957). A study of the "desensitization" produced by acetylcholine at the motor end-plate. J. Physiol, Lond. 138, 63-80.

Koketsu, K. and Minota, S. (1975). The direct action of adrenaline on the action potentials of bullfrog's (Rana catesbeiana) sympathetic ganglion cells. Experientia, 31, 822-823.

Kuba, K. and Koketsu, K. (1975). Direct control of action potentials by acetylcholine in bullfrog sympathetic ganglion cells. Brain Res., 89, 166-169.

KubA, K. and Koketsu, K. (1976). The muscarinic effects of acetylcholine on the action potential of bullfrog sympathetic ganglion cells. Jap. J. Physiol, 26, 703-716.

Minota, S. and Koketsu, K. (1977). Effects of adrenaline on the action potential of sympathetic ganglion cells in bullfrogs. Jap. J. Physiol., 27, 353-366.

Noble, D. (1975). The Initiation of the Heartbeat. Oxford, University Press.

Thesleff, S. (1955). The mode of neuromuscular block caused by acetylcholine, nicotine, decamethonium and succinylcholine. Acta Physiol. Scand., 34, 218-231. 